\title{
Cattle Grazing as a Biological Control for Broom Snakeweed: Vegetation Response
}

\author{
Michael H. Ralphs ${ }^{1}$ and Jeffery E. Banks ${ }^{2}$ \\ Authors are ${ }^{1}$ Rangeland Scientist, US Department of Agriculture-Agricultural Research Service, Poisonous Plant Research Laboratory, Logan, UT, \\ 84341, USA and ${ }^{2} J u a b$ County Agent, Utah State University Cooperative Extension, Nephi, UT 84648, USA.
}

\begin{abstract}
Broom snakeweed (Gutierrezia sarothrae [Pursh] Britton \& Rusby) increases and dominates rangelands following disturbances, such as overgrazing, fire, and drought. However, if cattle can be forced to graze broom snakeweed, they may be used as a biological tool to control it. Cattle grazed broom snakeweed in May and August 2004-2007. Narrow grazing lanes were fenced to restrict availability of herbaceous forage to force cattle to graze broom snakeweed. They used $50-85 \%$ of broom snakeweed biomass. Mature broom snakeweed plant density declined because of prolonged drought, but the decline was greater in grazed lanes. At the end of the study, density of mature plants in grazed lanes was 0.31 plants $\cdot \mathrm{m}^{-2}$, compared with 0.79 plants $\cdot \mathrm{m}^{-2}$ in ungrazed pastures. Spring precipitation in 2005 was $65 \%$ above average, and a new crop of seedlings established following the spring grazing trial. Seedling establishment was greater in the spring-grazed lanes in which the soil had been recently disturbed, compared with the ungrazed transects and summer-grazed lanes. The cattle were not able to use the large volume of new broom snakeweed plants in the spring-grazed pasture. They did reduce the number of seedlings and juvenile plants in the summer-grazed pasture. Intense grazing pressure and heavy use did not adversely affect crested wheatgrass (Agropyron cristatum [L.] Gaertn.) cover, and it was actually higher in the summer grazed lanes than the ungrazed control transects. In moderate stands of broom snakeweed, cattle can be forced to graze broom snakeweed and reduce its density without adversely affecting the associated crested wheatgrass stand.
\end{abstract}

\section{Resumen}

La escobilla (Gutierrezia sarothrae [Pursh] Britton \& Rusby) normalmente se incrementa y domina en pastizales después de que ha habido un disturbio tales como sobre-pastoreo, fuego o seguía. Sin embargo, si se obliga al ganado a consumir escobilla, este consumo puede utilizarse como una forma de control biológico. El ganado pastoreó escobilla durante mayo y agosto del 2004 al 2007. Se cercaron líneas angostas para restringir la disponibilidad de forraje herbáceo y de esta manera forzar al ganado a consumir escobilla. El ganado utilizó de 50 a $85 \%$ de la biomasa de la escobilla. La densidad de plantas maduras de escobilla disminuyó debido a la sequía prolongada, pero la disminución fue mayor en las líneas que se pastorearon. Al finalizar el estudio, la densidad de plantas maduras en las líneas pastoreadas fue de 0.31 plantas $\cdot \mathrm{m}^{2}$, comparado con 0.79 plantas $\cdot \mathrm{m}^{2}$ en los potreros no pastoreados. La precipitación de primavera del 2005 fue $65 \%$ por arriba del promedio, y un nuevo grupo de plántulas se estableció después del experimento de primavera. El establecimiento de plántulas fue mayor en las líneas pastoreadas en las cuales el suelo se había ocasionado disturbio recientemente comparado con los transectos no pastoreados y las líneas pastoreadas durante el verano. El ganado no pudo utilizar gran volumen de nuevas plantas de escobilla en los potreros pastoreados. El ganado redujo el número de plántulas, así como plantas jóvenes en el potrero pastoreado durante el verano. La intensa presión del pastoreo y la alta utilización no afectó negativamente la cobertura de Agropyron cristatum (L.) Gaertn. y de hecho fue mayor en la parcelas pastoreadas en el verano que en el control. En áreas con poblaciones moderadas de escobilla, el ganado se puede forzar a pastorear escobilla y reducir la densidad sin afectar adversamente la población de Agropyron cristatum (L.) Gaertn.

Key Words: biological control, forage allowance, grazing pressure, prescribed grazing

\section{INTRODUCTION}

Broom snakeweed (Gutierrezia sarothrae [Pursh] Britton \& Rusby) increases and dominates rangelands following disturbances such as overgrazing, fire, and drought (reviewed by McDaniel and Torrell 1987). However, if cattle can be induced to graze broom snakeweed, they may be used as a biological tool to control the weed (Ralphs et al. 2007). The goal of using livestock to control weeds is to manipulate patterns of defoliation to place the target plant at a competitive disadvantage relative to other plants in the community

Correspondence: Michael H. Ralphs, US Department of Agriculture-Agricultural Research Service, Poisonous Plant Research Laboratory, 1150 East 1400 North, Logan, UT 84341, USA. Email: Michael.Ralphs@ars.usda.gov

Manuscript received 17 March 2008; manuscript accepted 8 October 2008.
(Vallentine 1989). Implementing grazing management principles (such as kind of livestock, season of use, stocking rate, and duration) can increase the probability the target plant will be defoliated at the phenological stage, frequency, and intensity that is most detrimental, without undue harm to associated forage plants (Walker et al. 1994). Defoliation of broom snakeweed during its rapid, early growth in spring or during its flowering in late summer may be detrimental to its vigor and survival while not causing damage to associated grasses.

Ralphs et al. (2007) reported on cattle diets and use of broom snakeweed in this study. Mature bred Angus and AngusHereford cross cows were forced to graze broom snakeweed by confining them to small grazing lanes and limiting alternative forage. The cows were moved to new lanes each day to provide minimum feed and nutrients to maintain body condition. The cows grazed $62-95 \%$ of the broom snakeweed plants and used 
$50-85 \%$ of the broom snakeweed biomass. The objective of this study was to evaluate the response of the broom snakeweed and associated plant species to this high-intensity grazing trial that was intended to control broom snakeweed.

\section{METHODS}

The study site was located $12 \mathrm{~km}$ west of Nephi, Utah (lat $39^{\circ} 43^{\prime} 44.702^{\prime \prime} \mathrm{N}$, long $\left.111^{\circ} 53^{\prime} 28.891^{\prime \prime} \mathrm{W}\right)$. The original plant community was a Wyoming big sagebrush (Artemisia tridentata var. wyomingensis [Beetle \& Young] Welsh)/Indian ricegrass (Achnatherum hymenoides Roem. \& Schult.) plant community. A wildfire burned the site in July 1998, and it was seeded the following winter with crested wheatgrass (Agropyron cristatum [L.] Gaertn.). Broom snakeweed reinvaded the site, and its density averaged 2.1 plants $\cdot \mathrm{m}^{-2}$ at the beginning of the study. A 6-ha area was surrounded with an electric fence. The south half was grazed in spring, 18 May 2007 to 27 May 2004, 18 May 2005 to 1 June 2005, 5 May 2006 to 25 May 2006, and 8 May 2007 to 24 May 2007; and the north half was grazed in late summer, 17 August 2004 to 31 August 2004, 26 July 2005 to 20 August 2005, 1 August 2006 to 24 August 2006, and 1 August 2007 to 7 September 2007.

The amount of herbaceous forage (grass and forbs) available to the cows was restricted by reducing the pasture size to induce them to graze the broom snakeweed. Forage allowance is a specific index or measure of grazing pressure and is defined as the amount of forage available divided by the animal demand at a specific time (Vallentine 1989). Forage allowance was calculated using the standing crop at a point in time, divided by the predicted daily intake of the cows $\left(10 \mathrm{~kg} \cdot \mathrm{cow}^{-1} \cdot \mathrm{d}^{-1}\right)$. Grazing lanes were fenced each day, and the size was adjusted to provide a forage allowance that resulted in broom snakeweed use $>65 \%$ at the end of the day. The lanes were $138 \mathrm{~m}$ long, running the length of the pasture, and the width ranged from $3 \mathrm{~m}$ to $10 \mathrm{~m}$ wide, depending on the standing crop and desired forage allowance.

At the beginning of the study in 2004, paired grazed and ungrazed $10-\mathrm{m}$ transects were established within each grazing lane and at the end of the grazing lane in an ungrazed area. There were 27 grazing lanes and corresponding transects in the spring-grazed area, and 33 lanes and transects in the latesummer-grazed area. Transects were systematically placed perpendicular to the crested wheatgrass rows and in areas having dense broom snakeweed concentration. Permanent fiberglass pegs $(40 \mathrm{~cm}$ long) were placed at the beginning and end of each transect, and a tape was stretched between them. Foliar cover of each plant species was estimated by the lineintercept technique. Species cover was grouped into forage classes: 1) perennial bunchgrasses, which were dominated by crested wheatgrass, but small amounts of intermediate wheatgrass (Thinopyrum intermedium [Host] Barkworth \& D.R. Dewey) and Indian ricegrass were present; 2) Sandberg bluegrass (Poa secunda J. Presl), which was analyzed separately because of its low-growing stature and early spring maturation; 3) cheatgrass (Bromus tectorum L.); 4) forbs, and 5) broom snakeweed. A belt transect, $1 \mathrm{~m}$ wide, was placed over each transect, and the density and age classes of broom snakeweed plants were counted: mature plants had $>7$ stems, juvenile

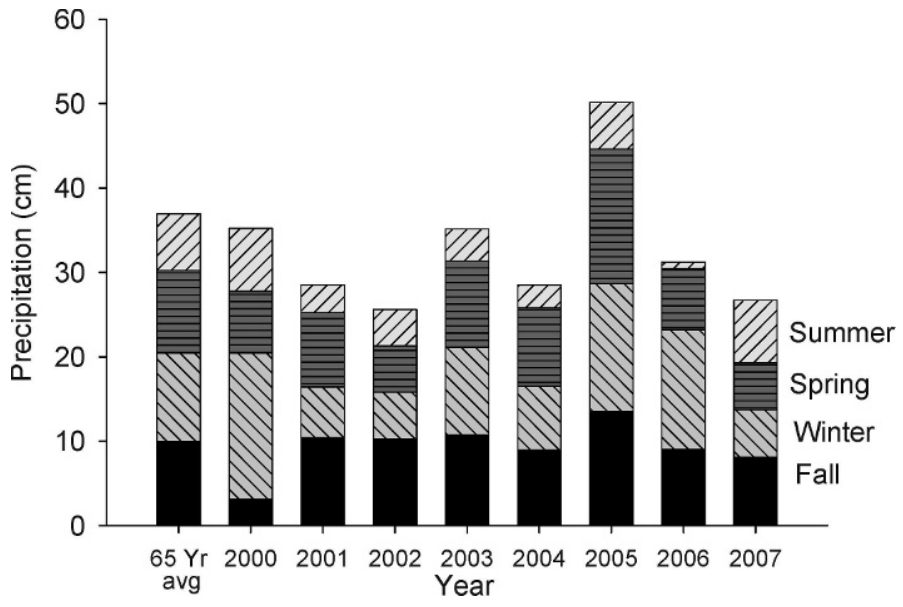

Figure 1. Seasonal water-year precipitation during the study, compared with the 65-yr long-term average.

plants had $<7$ stems, and seedlings were single stems that emerged that year. Transects were read the day before grazing. Seasonal precipitation was obtained from the Nephi, Utah, airport, about $5 \mathrm{~km}$ east of the study site at about the same elevation (Fig. 1).

Percentage of cover for each forage class and for the broom snakeweed age-class density were analyzed by repeatedmeasures analysis of variance comparing fixed effects of grazing treatment (grazed vs. ungrazed) and season, with year as the repeated measure. Lanes within grazing treatment and season were the random effects. Lanes were the experimental units to which the grazing treatments were applied. The covariance structure of the mixed model was first-order heterogeneous autoregressive. There were year-by-season interactions for both cover and density $(P<0.001)$, thus the model was reduced and the variables analyzed separately for each year in a covariate mixed model using the initial 2004 cover and density values as the covariate. This model compared the fixed effects of grazing treatment and season and their interactions each year, and transects within grazing treatment and season were the random effects.

A new crop of broom snakeweed seedlings germinated in June 2005, following the spring-grazing trial. The spring transects were read again in July, following the outbreak, to quantify seedling density. Subsequent density of seedlings plus juvenile plants (total young plants) were compared between treatments in 2006 and 2007 by a covariate mixed model (as described above) using 2005 seedling density as the covariate.

\section{RESULTS}

\section{Broom Snakeweed Density}

Data were pooled across seasons because neither the main effect of season $(P=0.96)$ or the season-by-grazing-treatment interaction $(P=0.93)$ was significant. There was a natural decline in the density of mature broom snakeweed plants from 2004 to 2005 in both grazed and ungrazed transects (Fig. 2). The study was conducted during an extended drought, and the drought's cumulative effects apparently resulted in a significant die-off. However, the grazing treatment caused greater 


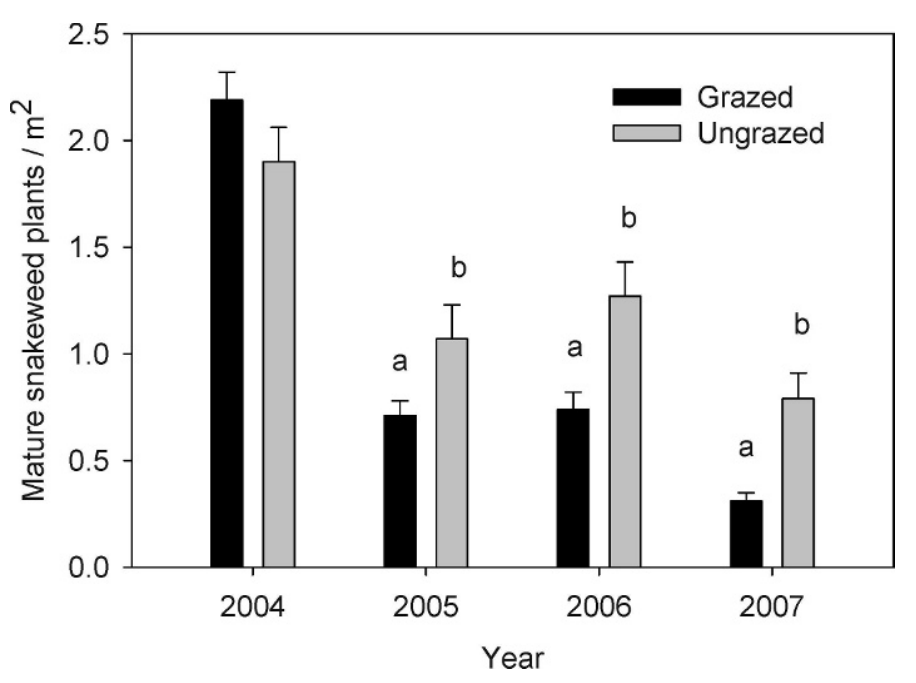

Figure 2. Density of mature snakeweed plants in the grazed pastures and ungrazed transects during the 4-yr study. Density was measured before grazing each year and reflects the cumulative effect of past use.

mortality in mature broom snakeweed plants than the ungrazed treatment in 2005 ( $P=0.04$; Fig. 2$)$.

Annual precipitation in 2005 was $25 \%$ above average (Fig. 1). There apparently was sufficient soil moisture for both broom snakeweed and grass because there was no further die-off in 2006 (Fig. 2). Spring precipitation in 2006 was below average, and there was very little summer precipitation, resulting in further die-off of mature plants in 2007. The decline was greater in the grazed pastures $\left(0.31\right.$ plants $\left.\cdot \mathrm{m}^{-2} \pm 0.04 \mathrm{SE}\right)$ compared with ungrazed transects $\left(0.79\right.$ plants $\cdot \mathrm{m}^{-2} \pm 0.12 \mathrm{SE} ; P=$ 0.0003 ) at the end of the study.

There were no seedlings or juveniles in 2004, reflecting the lack of establishment during the extended drought. Precipitation during the spring growing season in 2005 was $65 \%$ above average, stimulating an abundant germination of broom snakeweed seedlings in June. Establishment of seedlings in the spring-grazed pastures was more than double that in the ungrazed treatment (Fig. 3). Another crop of new seedlings germinated in the spring-grazed lanes in 2006 (Fig. 3). These seedlings survived, and juvenile plants reached 33 plants $\cdot \mathrm{m}^{-2}$ in the spring-grazed lanes in 2007.

Density of seedlings and juvenile plants was lower in the summer-grazed pastures $(P<0.0001$; Fig. 3$)$. Although they received the same precipitation, these pastures had not been grazed yet, and the soil was relatively undisturbed. The total number of seedlings and juveniles in the summer-grazed pasture declined over years, whereas they increased in the ungrazed transects in 2006 and $2007(P=0.0004)$.

\section{Vegetative Cover}

Broom snakeweed cover declined in 2005 following the decline in density of mature plants (Fig. 4). Seedlings contributed little to broom snakeweed cover in 2005 and 2006, but the large number of juvenile plants in the spring-grazed pasture increased cover in 2007 (Fig. 4). We would expect broom snakeweed cover to continue to increase as these plants mature and grow. In the summer-grazed pastures, broom snakeweed cover was lower in the grazed pasture compared with the ungrazed transects at the end of the study $(P=0.003)$.
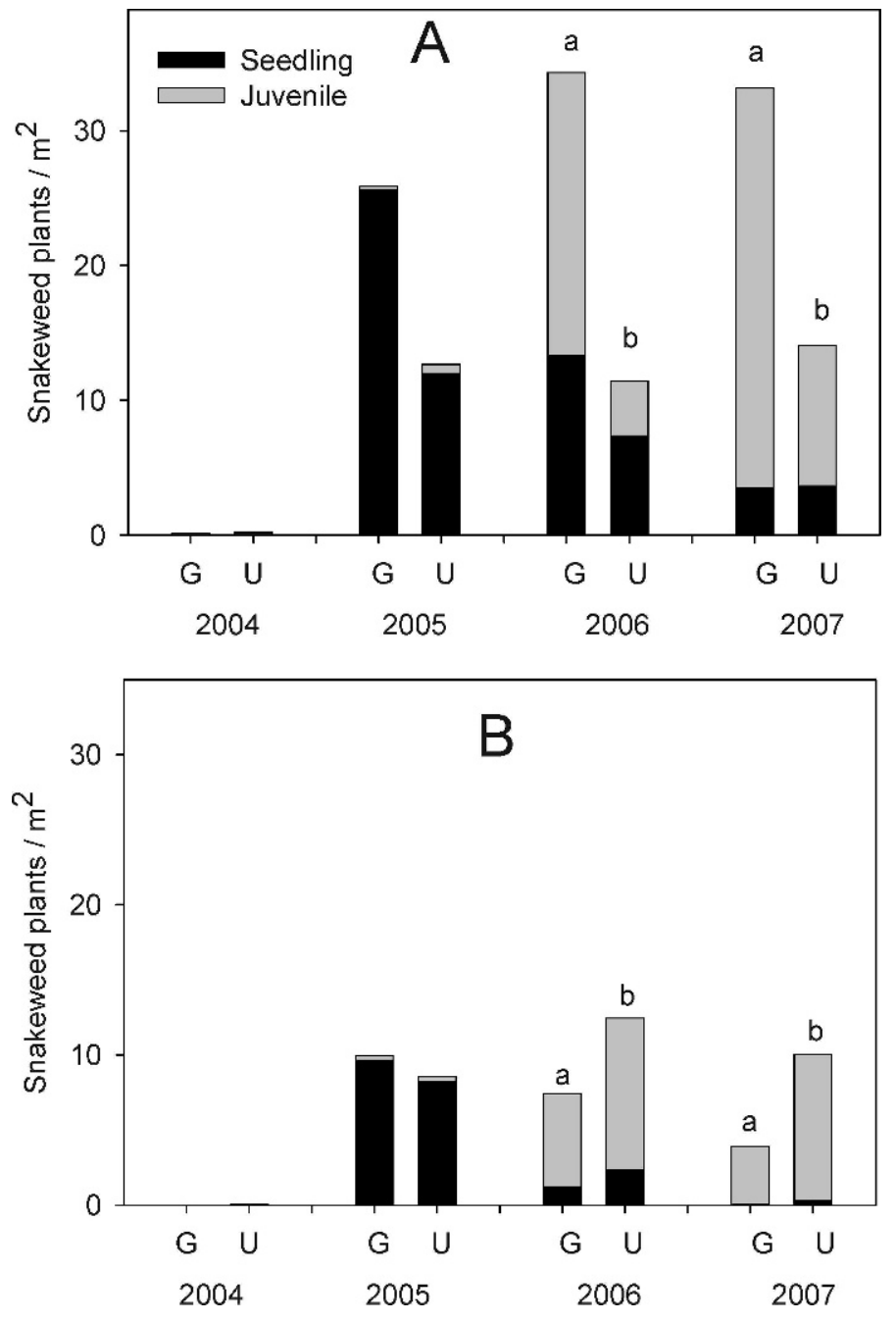

Figure 3. Density of snakeweed seedlings that established in 2005, and progressed to juveniles in 2006 and 2007, in grazed $(G)$ pastures and ungrazed $(U)$ transects in $\mathbf{A}$, spring-grazed pasture and $\mathbf{B}$, summergrazed pasture.

Crested wheatgrass cover increased in 2005 because of the wet year (Fig. 4). It maintained its cover in 2006 and 2007 in the grazed lanes, even under extremely heavy grazing pressure and trampling damage. The cover was actually higher in the summergrazed lanes than in ungrazed transects $(P<0.04)$. Cover of Sandberg bluegrass was greater in the ungrazed transects compared with the spring-grazed pastures $(3.6 \%$ vs. $1.8 \%$, data not shown), but there were no differences in the summer-grazed pasture $(2 \%$ cover $)$. Forb cover was greater in the spring-grazed than the summer-grazed pastures ( $6 \%$ vs. $2 \%$, data not shown), but there were no differences between grazed or ungrazed areas.

Cheatgrass cover was lower in spring-grazed than summergrazed pasture $(P<0.0001$; Fig. 4$)$. Within seasons, cheatgrass cover was lower in the grazed lanes than the ungrazed transects $(P=0.0018)$.

\section{DISCUSSION}

Grazing reduced the density of the original, mature broom snakeweed plants in both spring-grazed and summer-grazed 

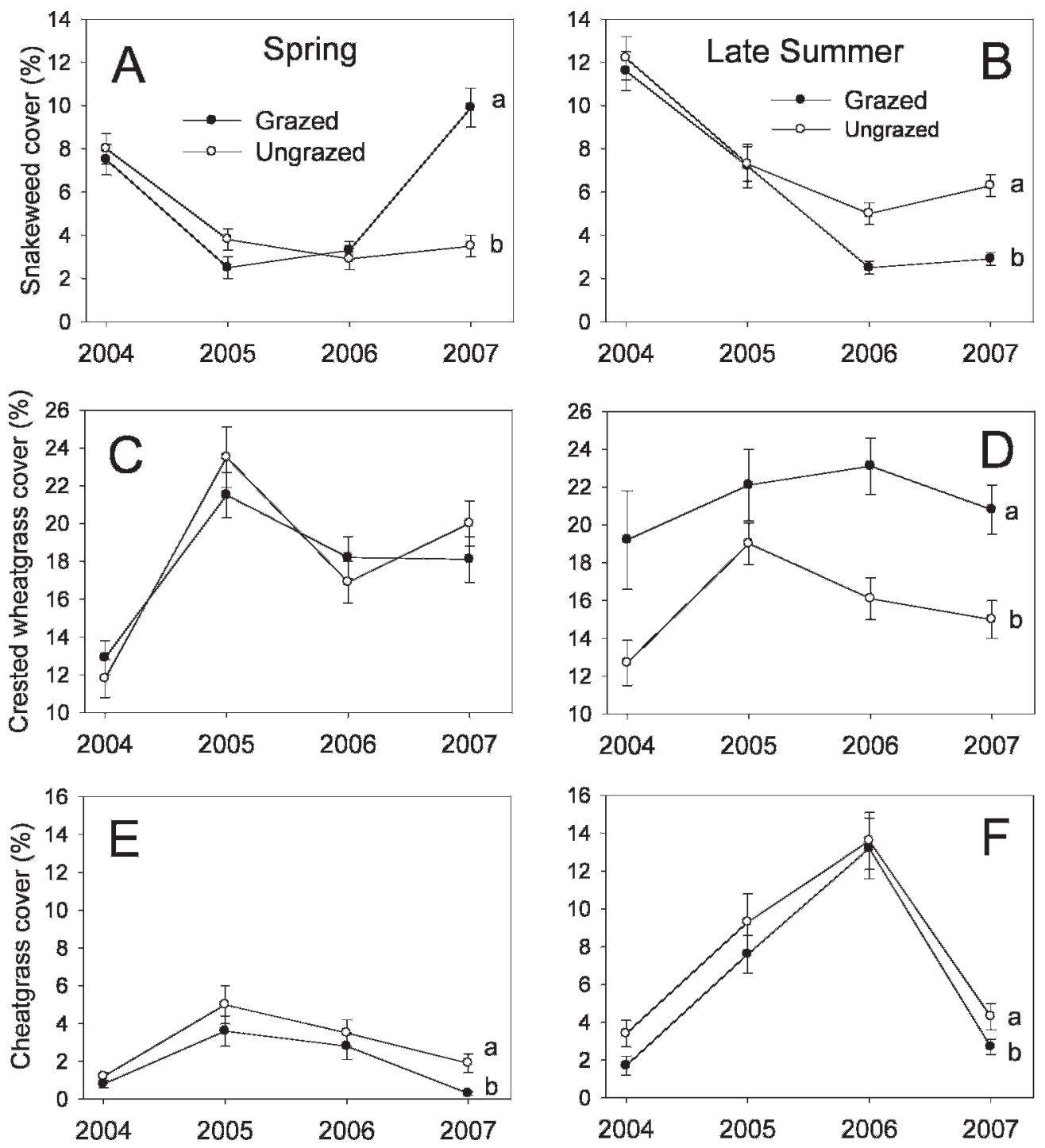

Figure 4. Foliar cover of snakeweed in A, spring and B, summer pastures; perennial bunchgrasses in $\mathbf{C}$, spring and $\mathbf{D}$, summer pastures; and cheatgrass in $\mathbf{E}$, spring and $\mathbf{F}$, summer pastures during the 4-yr study.

lanes to a greater degree than the natural decline in ungrazed transects. At the same time, crested wheatgrass cover increased in 2005 in response to the above-average precipitation and maintained its cover despite the extremely heavy grazing pressure in both spring-grazed and summer-grazed lanes. At the end of the study, there was no difference in crested wheatgrass cover between the spring-grazed and ungrazed transects, but its cover in the summer-grazed lanes was greater than in the ungrazed transects.

Reduction in competition is perhaps more important in determining regrowth potential of grasses than severity of defoliation (Mueggler 1972). Grass morphology is such that the apical meristem is not elevated until elongation of the flower stalk. Defoliation of leaves before stem elongation allows intercalary meristems at leaf bases to continue to differentiate and elongate (Briske and Richards 1995; Dahl 1995) and to rapidly replace photosynthetic leaf tissue to support continued growth of the plant. Furthermore, crested wheatgrass is the most grazing-tolerant grass in the western United States, primarily because of its rapid replacement of leaf photosyn- thetic tissue (Caldwell 1981), its early spring root growth, and its subsequent ability to extract soil moisture (Eissenstat and Caldwell 1988).

In contrast, the apical meristem of broom snakeweed is located at the tip of the stem. Any level of defoliation would remove this in both spring and late-summer grazing trials. Any further growth must come from the slow process of new bud development from the crown. Mature broom snakeweed die-off occurred following the dry years of 2004 and 2006. Mortality of mature plants was greater in the grazed lanes, which was likely enhanced by the rapid regrowth capacity of crested wheatgrass and its subsequent use of the limited soil moisture. Although the associated grasses were also totally defoliated, they were able to regrow and use soil moisture and nutrients, thus preempting the resource use by broom snakeweed. This accomplished the goal of controlling broom snakeweed without undue harm to the associated forage (Vallentine 1989; Walker et al. 1994).

There was no decline of mature broom snakeweed plants between 2005 and 2006 in either grazed lanes or ungrazed transects. Apparently, there was sufficient soil moisture for 
both grass and broom snakeweed survival in the high water year of 2005 .

A new crop of broom snakeweed seedlings established themselves after the spring-grazing trial in 2005. Total wateryear precipitation in 2005 was $25 \%$ above average, and spring precipitation was $65 \%$ above average. A heavy, spring snow storm occurred during the grazing trial, which saturated the soil for several days. The intense grazing removed all herbaceous standing crop, and trampling disturbed the soil surface. These conditions were ideal for establishment of broom snakeweed seedlings (McDaniel et al. 2000). Soil moisture availability is a critical factor in broom snakeweed germination and survival (Wan et al. 1993a). At least $4 \mathrm{~d}$ of consecutive, saturated soil conditions (Wood et al. 1997), with moderating day/night temperatures (Mayeaux and Leotta 1981), are required for establishment.

The fluctuating resource-availability theory of invasibility (Davis et al. 2000) suggests that a plant community becomes more susceptible to invasion whenever there are unused resources. This occurs when there is either an increase in resource supply (a high water year) or a decrease in resource use (a disturbance, such as grazing, which reduces immediate water use of the dominant grasses). Even though crested wheatgrass recovered rapidly from defoliation, the brief period of reduced competition may have been sufficient for broom snakeweed seedling establishment. This occurred throughout the larger crested wheatgrass seeding surrounding our study site. Broom snakeweed outbreaks are common in years of above-average precipitation (McDaniel 1989; Wood et al. 1997; McDaniel et al. 2000; Ralphs and Sanders 2002).

In contrast to the spring-grazing treatment, grazing reduced broom snakeweed seedling establishment in the summer-grazed lanes. Soils for the summer pasture had not yet been disturbed, and the rapidly growing crested wheatgrass provided competition for soil moisture for the establishing broom snakeweed seedlings. When the pasture was grazed in August, trampling damage destroyed many of the broom snakeweed seedlings. Use of these juvenile plants was also heavy during the summer 2006 grazing trial, further reducing the density of juveniles in 2007.

Grass competition in our summer-grazed lanes likely contributed to reduced establishment of broom snakeweed seedlings. Broom snakeweed seedlings are very sensitive to interspecific interference from established grasses (Thacker et al. 2009). However, once seedlings establish and mature into juveniles, they are very competitive and difficult to kill. In a companion clipping study, adjacent to our grazing site (Ralphs 2009), defoliation of established broom snakeweed juveniles was not detrimental, and they flourished when grasses and all other associated vegetation were defoliated. Broom snakeweed can compete with bunchgrasses because their deeper roots can extract moisture from deeper subsoil (Wan et al. 1993b).

Several reviews have reported on the use of livestock grazing to control weeds (Doescher et al. 1987; Brock 1988; Vallentine 1989; 1990; Gillen and Scifres 1991; Olson and Lacey 1994; Popay and Field 1996). General principles (Walker 1994; Frost and Launchbaugh 2003) and prescriptions for specific plants have been given (Launchbaugh 2006). Long-term grazing studies showed heavy stocking rates reduced weedy shrub species. On shortgrass prairies in Colorado, heavy season-long stocking rates of heifers that removed $60-68 \%$ of current-season grass standing crop eliminated broom snakeweed and other half-shrubs, without harming blue grama (Bouteloua gracilis [Willd. ex Kunth] Lag. ex Griffiths) or buffalograss (Bouteloua dactyloides [Nutt.] J.T. Columbus; Hart and Ashby 1998). In a series of reports documenting long-term response $(72 \mathrm{yr})$ of threetip sagebrush (Artemisia tripartita Rydb.) in Idaho, heavy fall grazing by sheep (60 sheep-days $\cdot$ acre $^{-1}$ ) reduced sagebrush cover to $13.9 \%$, compared with $23.5 \%$ in moderately grazed spring pastures, and cover increased in perennial grasses $(16.2 \%$ vs. $10.6 \%$ ) and forbs (8.5\% vs. $2.3 \%$ ), respectively (Mueggler 1950; Laycock 1967; Bork et al. 1998). Merrill and Taylor (1976) reported heavy browsing by goats following chaining reduced regrowth of ashe juniper (Juniperus ashei J. Buchholz), redberry juniper (J. pinchotii Sudw.), shin oak (Quercus mohriana Buckley ex Rydb.), live oak (Q. virginiana Mill), and honey mesquite (Prosopis glandulosa Torr.) by greater than $90 \%$ after 5 years while increasing grass cover by $10 \%$ in the mixed grass community.

Recent high-intensity grazing trials similar to ours have also been successful in reducing weeds. Two field-scale grazing trials confined bands of dry ewes to small areas of mountain big sagebrush (Artemisia tridentata Nutt. subsp. vaseyana [Rydb.] Beetle) in the fall. The ewes were fed high-protein and energy supplements to maintain body condition. The ewes stripped the sagebrush plants, which reduced sagebrush cover the next grazing season $40 \%$ on Parker Mountain (in central Utah) and $25 \%$ on Blue Mountain (in northeastern Utah; R. Banner, personal communication, September 2008). Olson et al. (1997) reported that following $3 \mathrm{yr}$ of short, intense grazing periods during summer, sheep used $75-95 \%$ of spotted knapweed (Centaurea stoebe L.) and Idaho fescue (Festuca idaboensis Elmer) plants and prevented knapweed density from increasing, whereas its density increased threefold in ungrazed areas. Density of Idaho fescue was maintained, and frequency of Kentucky bluegrass (Poa pratensis L.) increased under this intensive grazing treatment. Ralphs et al. (2007) concluded that grazing pressure was the major factor forcing livestock to graze weeds. Short, intense grazing periods can force livestock to graze target plants, and rapid recovery of grasses can further compete against the weeds for limited soil resources.

\section{MANAGEMENT IMPLICATIONS}

Increasing grazing pressure by restricting forage availability in narrow grazing lanes forced cattle to graze broom snakeweed and reduced its population. Managers can control grazing pressure by manipulating pasture size, stock density, and duration, thereby forcing livestock to graze most types of unwanted vegetation. This high-intensity grazing strategy did not adversely affect crested wheatgrass cover in our study. Grasses are adapted to defoliation and rapidly replace photosynthetic tissue and resume growth. If soil moisture and nutrient resources are available, rapid regrowth of grasses can use these resources before the target weed can respond and develop new foliage. The stress of defoliation on the target weed and competition from grasses rapidly using soil resources combined to enhance mortality of broom snakeweed. Further research is necessary to determine whether this grazing strategy can be successful at a management scale. 


\section{LITERATURE CITED}

Bork, E. W., N. E. WeSt, and J. W. WaLker. 1998. Cover components on long-term seasonal sheep grazing treatments in three-tip sagebrush steppe. Journal of Range Management 51:293-300.

BRISKE, D. D., AND J. H. Richards. 1995. Plant responses to defoliation: a physiological, morphological and demographic evaluation. In: D. J. Beduna and R. E. Sosebee [EDS.]. Wildland plants: physiological ecology and developmental morphology. Denver, CO, USA: Society For Range Management. p. 635-709.

BRock, J. H. 1988. Livestock: biological control in brush/weed management programs. Rangelands 10:32-34.

Caldwell, M. M., J. G. Richards, D. A. Johnson, R. S. Nowak, and R. S. Dzurec. 1981. Coping with herbivory: photosynthetic capacity and resource allocation in two semiarid Agropyron bunchgrasses. Oecologia 50:14-24.

DaHL, B. E. 1995. Developmental morphology of plants. In: D. J. Beduna and R. E. Sosebee [EDS.]. Wildland plants: physiological ecology and developmental morphology. Denver, CO, USA: Society for Range Management. p. 22-58.

Davis, M. A., J. P. Grime, And K. Thompson. 2000. Fluctuating resources in plant communities: a general theory of invisibility. Journal of Ecology 88:528-534.

Doescher, P. S., S. D. Tesch, and M. Alejandro-Castro. 1987. Livestock grazing: a silvicultural tool for plantation establishment. Journal of Forestry 85:29-37.

Eissenstat, D. M., and M. M. Caldwell. 1988. Seasonal timing of root growth in favorable microsites. Ecology 69:870-873.

Frost, R. A., and K. L. Launchbaugh. 2003. Prescription grazing for rangeland weed control. Rangelands 25:43-47.

Gillen, R. L., AND C. J. Scifres. 1991. Selective grazing as a weed control method. In: D. Pimentel [ED.]. CRC handbook of pest management in agriculture. Boca Raton, FL, USA: CRC Press. p. 369-376.

HART, R. H., AND M. M. AshBy. 1998. Grazing intensities, vegetation and heifer gains: 55 years on shortgrass. Journal of Range Management 55:392-398.

LaunchBAuGH, K. 2006. Targeted grazing: a natural approach to vegetation management and landscape enhancement. Englewood, CO, USA: American Sheep Industry Association.

LAYcock, W. A. 1967. How heavy grazing and protection affect sagebrush grass ranges. Journal of Range Management 20:206-213.

MayeauX, H. S., JR., AND L. LeotTA. 1981. Germination of broom snakeweed (Gutierrezia sarothrae) and threadleaf snakeweed (G. microcephala) seed. Weed Science 29:530-534.

McDaniel, K. C. 1989. Snakeweed populations in New Mexico, 1979-1989. In: E. W. Huddleston and R. E. Pieper [EDs.]. Snakeweed: problems and perspectives. New Mexico State University, Agriculture Experiment Station Bulletin 751:13-25.

McDaniel, K. C., D. B. Carrol, and C. R. Hart. 2000. Broom snakeweed establishment on blue grama grasslands after fire and herbicide treatments. Journal of Range Management 53:239-245.
McDaniel, K. C., and L. A. Torell. 1987. Ecology and management of broom snakeweed. In: J. L. Capinera [ED.]. Integrated pest management on rangeland, a shortgrass prairie perspective. Boulder, CO, USA: Westview Press. p. 101-115.

MerRilL, L. B., And C. A. Taylor. 1976. Take note of the versatile goat. Rangeman's Journal 3:74-76.

MueggleR, W. F. 1950. Effects of spring and fall grazing by sheep on vegetation of the Upper Snake River Plains. Journal of Range Management 3:308315.

Mueggles, W. F. 1972. Influence of competition on response of bluebunch wheatgrass to clipping. Journal of Range Management 25:88-92.

OLSON, B. E., AND J. R. LACEY. 1994. Sheep: a method for controlling rangeland weeds. Sheep \& Goat Research Journal Special issue 1994:105-112.

Olson, B. E., R. T. Wallander, and J. R. Lacey. 1997. Effects of sheep grazing on spotted knapweed-infested Idaho fescue community. Journal of Range Management 50:366-390.

Popay, I., AND R. FieLd. 1996. Grazing animals as weed control agents in pastures. Weed Technology 10:217-231.

RalpHS, M. H. 2009. Response of broom snakeweed (Gutierrezia sarothrae) to defoliation. Invasive Plant Science and Management (in press).

Ralphs, M. H., And K. D. Sanders. 2002. Population cycles of broom snakeweed in the Colorado Plateau and Snake River Plains. Journal of Range Management 55:406-411.

Ralphs, M. H., R. D. WiedmeieR, and J. E. Banks. 2007. Decreasing forage allowance can force cattle to graze broom snakeweed (Gutierrezia sarothrae) as a potential biological control. Range Ecology and Management 60:487-497.

Thacker, E. T., M. H. Ralphs, and T. A. Monaco. 2009. A comparison of inter- and intra-specific interference on broom snakeweed (Gutierrezia sarothrae) seedling growth. Invasive Plant Science and Management (in press).

Vallentine, J. F. 1989. Biological plant control. In: Range development and improvements. New York, NY, USA: Academic Press. p. 72-87.

Vallentine, J. F. 1990. Vegetation manipulation by selective grazing. In: Grazing management. New York, NY, USA: Academic Press. p. 254-258.

Walker, J. W., S. L. Kronberg, S. L. A. Rowally, and N. E. West. 1994. Managing noxious weeds with livestock: studies on leafy spurge. Sheep Research Progress Report 3. Dubois, ID, USA: US Department of AgricultureAgricultural Research Service. p. 125-135.

Wan, C., R. E. Sosebee, and B. L. McMıchael. 1993a. Broom snakeweed responses to drought, II: root growth carbon allocation and mortality. Journal of Range Management 46:360-363.

Wan, C., R. E. Sosebee, and B. L. McMichael. 1993b. Soil water extraction and photosynthesis in Gutierrezia sarothrae and Sporobolus cryptandrus. Journal of Range Management 46:425-430.

Wood, B. L., K. C. McDaniel, and D. Clason. 1997. Broom snakeweed (Gutierrezia sarothrae) dispersal, viability and germination. Weed Science 45:77-84. 